\title{
A STOCHASTIC FRONTIER APPROACH TO MEASURING INEFFICIENCY OF LOCAL COMMUNITIES IN BOSNIA AND HERZEGOVINA
}

Lejla Lazović-Pita, Lamija Šćeta

\section{Abstract}

The significance and methods of measuring inefficiency of local communities has been gaining prominence in the last decade. The purpose of this paper is to empirically investigate the level of technical inefficiency in the sample of local communities in Bosnia and Herzegovina (BiH) for the year of 2017. We implement parametric stochastic frontier analysis (SFA) to conduct an input-oriented stochastic parametric approach to measuring technical inefficiency of local communities in BiH. The results of our work are complementary to previous research indicating relative technical inefficiency of local communities in $\mathrm{BiH}$. On average, $\mathrm{BiH}$ local communities' total expenditures can be reduced by 46.8 percent without reducing output levels to achieve the result of the local community on the best practice frontier. Since our analysis and selection of variables are driven by data availability, the future research plans to include more variables.

Key words: local communities, technical inefficiency, stochastic frontier analysis, Bosnia and Herzegovina

JEL: D24, H72

\section{INTRODUCTION}

The academic interest in local communities in $\mathrm{BiH}$ in the last twenty years was mostly scarce and dealt with aspects of fiscal federalism and decentralisation, and intergovernmental fiscal relations (for example Fox and Wallich 1997, Begić 2000, Kreso 2005 or Werner, Guihéry and Djukic 2006). Possible reasons for the little interest in the topic might be due to the complexity of $\mathrm{BiH}$ constitutional and administrative set-up and the asymmetric jurisdiction of local communities across the country. BiH is organised as an asymmetric (con)federation with two entities - Federation of $\mathrm{BiH}$ (FBiH) and Republika Srpska (RS)i. The two entities' constitutions and two different laws on local self-government define the position of local communities in $\mathrm{BiH}$ in terms of the organisation of local communities as either municipalities or cities as well as other relevant issues at the local level.

Lejla Lazović-Pita, PhD

(corresponding author)

Associate Professor

School of Economics and Business,

University of Sarajevo, BiH

Address: Trg oslobodjenja-Alija Izetbegovic 1,

Sarajevo

E-mail: lejla.lazovic@efsa.unsa.ba

ORCID: 0000-0001-9421-1842

Lamija Šćeta, PhD

Associate Professor

School of Economics and Business,

University of Sarajevo, BiH

E-mail: lamija.sceta@efsa.unsa.ba

ORCID: 0000-0002-0410-0311 
The global financial crisis (GFC) of 2008-2009 together with administrative rigidity and political deadlock in $\mathrm{BiH}$ have put a significant pressure on local budgets. A rise in local budget expenditures together with high dependence on shared revenues, which decreased as a direct result of GFC on the one side, and limited ability and authority over the collection of own revenues on the other, have in turn resulted in (increasing) local budget deficits. Since 2009, local budget deficits have been covered by higher local public borrowing - either loans taken from banks or by issuing of securities, namely municipal bonds (Basarić, Branković, and Lazović-Pita 2018). In fact, Basarić, Branković, and Lazović-Pita (2018) state that from 2008 until 2015 the total aggregate local public debt (loans and issued securities) has more than doubled.

Even though the academic discussion and the available literature that deals with methods of measuring efficiency in local communities are very exhaustive worldwide, this is not the case in $\mathrm{BiH}$. In fact, the available literature that deals with efficiency of local communities in $\mathrm{BiH}$ was only recently analysed in the papers by Soko (2018) and Soko and Zorič (2018). Soko (2018), and Soko and Zorič (2018) employed the most used method for measuring efficiency of local communities on the example of $\mathrm{BiH}$ - the data envelopment analysis (DEA). In this paper, we wanted to test alternative composite approach to measuring efficiency - the stochastic frontier analysis (SFA) on the example of $\mathrm{BiH}$ local communities. Hence, the purpose and the motivation for this research is to explore the level of inefficiency of local communities in $\mathrm{BiH}$ by using the SFA. We also aim to contribute towards scarce literature on measuring technical inefficiency of local communities in $\mathrm{BiH}$. In line with the defined purpose, the primary research question was asked: Through the application of the SFA model, to what extent are the local communities in $\mathrm{BiH}$ technically inefficient?

Thus, we measure the level of technical inefficiency of local communities in $\mathrm{BiH}$ for the year of 2017 by using the total local expenditures (in BAM) as a dependent variable. Several independent variables assigned as local expenditures in $\mathrm{BiH}$ will also be used and explained in the methodology section. After the introduction, the paper will be divided into four additional chapters - literature review, data and methodology, results and discussion from econometric estimation followed by the conclusion section. Since little research related to this topic has been done in $\mathrm{BiH}$, we believe that this paper will contribute towards greater understanding and shed some light on the importance of local communities in $\mathrm{BiH}$ in their adequate provision of local goods and services, which is in line with Tiebout hypothesis (Tiebout 1956).

\section{LITERATURE REVIEW}

The academic literature related to local communities has been gaining prominence in the last twentyfive years. The results from the Web of Science core collection search with three keywords - local and expenditures and revenues show some 575 records (Web of Science 2019). The results also indicate that since the early 1990s - 1995, when only six records were noted, the number of records constantly increased until 2018 (55 records). Radulović and Dragutinović (2015) state that there are two approaches to measuring efficiency of local government services provision. The first one assesses the efficiency of a single service delivered by local governments (for example, communal services, waste management, etc.) and the other approach is based on the so-called composite approaches to measuring efficiency in terms of providing overall local government efficiency score. The composite approaches to measuring efficiency analyse the overall performance of the local level (or higher-level governments) since "they do not restrict their attention to one specific public good, but rather allow for a more general view on government performance" (Kalb, Geys, and Heinemann 2011, p. 3). There are three methods based on the composite approaches to measuring efficiency - DEA, Free Disposable Hull (FDH) and SFA method.

In terms of the application of the three methods, Narbón-Perpiñá and De Witte (2018) provide the most exhaustive and detailed systematic literature overview on measures and methods related to the local government's efficiency based upon 84 empirical studies they have identified. Hence, Narbón-Perpiñá and De Witte (2018) provided the research results from three largest scientific databases, namely, Web of Science, Elsevier Scopus and Google Scholar over 1990-2016 period and focused on the systematization of all input and output variables that were used in the studies globally. Their results justify the choices of variables we have provided in our analysis. Furthermore, as the results of Narbón-Perpiñá and De Witte (2018) research show, the most used methods are the combination of DEA and SFA. Hence, we have decided to apply SFA method to the case of BiH's local communities to complement previous research on $\mathrm{BiH}$. Other authors such as Boetti, Piacenza, and Turati (2012), Nikolov and Hrovatin (2013) and Soko and Zorič (2018) have also provided a similar literature review but mainly focused on the European countries.

Since it has not been previously done, our literature review focuses only on literature review in the sub-set of (post)-transition countries, namely former Yugoslav countries. In Table 1 we provide a literature overview of academic research related to measuring (in) 
efficiency of sub-central government tiers -either regional counties or local communities. Systematisation provided in the works by Boetti, Piacenza, and Turati (2012), Nikolov and Hrovatin (2013) and Soko and Zorič (2018) and Narbón-Perpiñá and De Witte (2018) is applied in Table 1, which summarises the most recent relevant research conducted in the countries of former Yugoslavia, clearly stating the country, authors, method(s), variables and obtained results.
From Table 1, we can confirm that the DEA method is the most widely used method in the conducted research on local communities/counties in former Yugoslav countries. We can also determine that in most countries, SFA method has also been used to compare and test the results from two methods - DEA and SFA and we wish to contribute towards this analysis in the case of $\mathrm{BiH}$.

Table 1. Literature review of relevant regional and local efficiency studies in former Yugoslav countries

\begin{tabular}{|c|c|c|c|c|}
\hline $\begin{array}{l}\text { Country (analysed } \\
\text { level of government) }\end{array}$ & Authors & $\begin{array}{l}\text { Method(s) } \\
\text { used }\end{array}$ & $\begin{array}{l}\text { Variables (dependent variables/inputs; } \\
\text { independent variables/outputs) }\end{array}$ & $\begin{array}{l}\text { Results } \\
\text { and mean } \\
\text { efficiency }\end{array}$ \\
\hline $\begin{array}{l}\text { Croatia (regional } \\
\text { analysis - counties) }\end{array}$ & $\begin{array}{l}\text { Hodžić and } \\
\text { Muharemović } \\
\text { (2019) }\end{array}$ & DEA & $\begin{array}{l}\text { Gross earnings of the employed, material expenses } \\
\text { and borrowing costs (inputs), number of business- } \\
\text { es in counties, number of primary and secondary } \\
\text { schools and population per county (output) }\end{array}$ & $0.88-0.96$ \\
\hline $\begin{array}{l}\text { BiH (local } \\
\text { communities) }\end{array}$ & $\begin{array}{l}\text { Soko (2018) and } \\
\text { Soko and Zorič } \\
\text { (2018) }\end{array}$ & DEA & $\begin{array}{l}\text { Total budget expenditure (input), population; num- } \\
\text { ber of pupils in primary school; length of roads; } \\
\text { number of doctors (outputs) }\end{array}$ & 0.7115 \\
\hline $\begin{array}{l}\text { Serbia (local } \\
\text { communities) }\end{array}$ & $\begin{array}{l}\text { Radulović and } \\
\text { Dragutinović } \\
\text { (2015) }\end{array}$ & SFA & $\begin{array}{l}\text { Current expenditures (input), population, munici- } \\
\text { pal roads, water supply, kindergartens, primary and } \\
\text { secondary education, social services (output) }\end{array}$ & $0.67-0.85$ \\
\hline $\begin{array}{l}\text { North Macedonia } \\
\text { (local communities) }\end{array}$ & $\begin{array}{l}\text { Nikolov and } \\
\text { Brosio (2015) }\end{array}$ & SFA & $\begin{array}{l}\text { Municipal expenditures (input), age class as a proxy } \\
\text { for the competencies of municipalities like child } \\
\text { and elderly care, primary and secondary education } \\
\text { and road maintenance (output) }\end{array}$ & $\ldots$ \\
\hline $\begin{array}{l}\text { Slovenia (local } \\
\text { communities) }\end{array}$ & Pevcin (2014) & $\begin{array}{l}\text { DEA and } \\
\text { SFA }\end{array}$ & $\begin{array}{l}\text { Total expenditures (input), population, primary and } \\
\text { secondary education, elderly care and business } \\
\text { development (outputs) }\end{array}$ & $0.75-.0 .88$ \\
\hline $\begin{array}{l}\text { Slovenia (local } \\
\text { communities) }\end{array}$ & Pevcin (2013) & SFA & $\begin{array}{l}\text { Total expenditures (input), population, primary and } \\
\text { secondary education, elderly care and business } \\
\text { development (outputs) }\end{array}$ & $0.75-0.78$ \\
\hline $\begin{array}{l}\text { Croatia (regional } \\
\text { analysis-counties) }\end{array}$ & Rabar (2013) & DEA & $\begin{array}{l}\text { Registered unemployment rate, support allow- } \\
\text { ance users (input), share of secondary sector, GDP, } \\
\text { graduated students, level of import coverage by } \\
\text { export, gross fixed capital formation in fixed assets, } \\
\text { share of secondary sector (output) }\end{array}$ & 0.7 \\
\hline $\begin{array}{l}\text { North Macedonia } \\
\text { (local communities) }\end{array}$ & $\begin{array}{l}\text { Nikolov and } \\
\text { Hrovatin (2013) }\end{array}$ & DEA/SFA & $\begin{array}{l}\text { Current expenditures (input), population by age } \\
\text { categories as a proxy of different services and } \\
\text { length of asphalt roads }\end{array}$ & 0.59 \\
\hline $\begin{array}{l}\text { Croatia (regional } \\
\text { analysis- counties) }\end{array}$ & $\begin{array}{l}\text { Škuflić, Rabar, } \\
\text { and Šokčević } \\
\text { (2010) }\end{array}$ & DEA & $\begin{array}{l}\text { Number of graduate students, number of active } \\
\text { legal entities, level of foreign direct investment, } \\
\text { investment and exports (inputs), level of the gross } \\
\text { domestic product and gross wages (outputs) }\end{array}$ & 0.85 \\
\hline
\end{tabular}

N.B. results from Web of Science, Elsevier Scopus and Google Scholar databases do not provide any data regarding application of any of the three models in assessing efficiency of local communities in Montenegro and Kosovo.

Source: authors. 
According to the available literature, in the measures of efficiency of local communities, it is crucial to determine whether "the cost efficiency of decisionmaking units will be measured by parametric and nonparametric methods" (Štastná and Gregor 2011, p. 2; Štastná and Gregor 2015). In the works by Soko (2018) and Soko and Zorič (2018), non-parametric deterministic DEA method for local communities in BiH for the year 2015 was used. Their results indicate relative inefficiency of local communities, where only 23 local communities or 16 percent of local communities in $\mathrm{BiH}$ are efficient with the average efficiency score of 0.71 . In the discussion section, due to methodological limitations, we briefly comment on the results obtained by the DEA method and the results of the SFA method as a parametric-stochastic approach to measuring technical inefficiency for BiH local communities.

\section{DATA AND METHODOLOGY}

According to the two entity constitutions ( $\mathrm{FBiH}$ and $\mathrm{RS})$, local self-government in $\mathrm{BiH}$ is organised as municipalities and cities. The two entities have different constitutional organisation (FBiH is federal and RS is unitary) which directly affects the number of sub-central levels of government (namely, existence of cantons in the FBiH unlike in the RS). Two entity laws on local self-government regulate, inter alia, organisation, assigned responsibilities, scope of work and expenditure assignments of local communities in each entity. Even though each entity law on local self-government defines criteria for a municipality to become a city (or criteria for several municipalities to form a city), there is no substantial difference between municipalities and cities in their expenditure assignments.

Similar to other (post)transition countries which experienced an increase in the number of local communities after entering the transition process (for example Croatia or Slovenia), $\mathrm{BiH}$ also has had an increase in the number of local communities in the transition process. However, the reasons for a greater number of local communities in other (post) transition countries and $\mathrm{BiH}$ are opposite - in $\mathrm{BiH}$ they were driven by non-economic reasons and the new $\mathrm{BiH}$ constitution under the Dayton Peace Agreement. There are 142 local communities in $\mathrm{BiH}-79$ in the $\mathrm{FBiH}$ and 63 in the RS. However, if we look at the number of local budgets being brought in each entity, the total number is higher by three (Brčko District and two cities formed out of several municipalities - City of Sarajevo and City of East Sarajevo, none of which is considered in this analysis). From the 142 local communities in $\mathrm{BiH}$, we have taken a sample of 129 local communities and analysed them for the year 2017. We excluded 13 local communities from the sample for the following reasons:

- 12 local communities due to a lack of official dataii;

- 1 local community that was recently established in the RS and therefore data were not available.

According to Institute for Statistics of the $\mathrm{FBiH}$ (2018) and the RS Institute of Statistics (2018), the data for 13 excluded local communities either do not exist/ are not published, or the data (for example, number of employed persons, pupils or doctors) has been added to the larger neighbouring local community. The excluded local communities account for less than one percent of the total population in $\mathrm{BiH}$ for 2017.

Pursuant to the papers by Narbón-Perpiñá and De Witte (2018), there are several options for the definition and the use of dependent variables (input) in the SFA model estimation such as: current expenditures, total expenditures, personnel expenditures, capital and financial expenditures or other expenditures. In our estimation, we use the total local expenditures as a dependent variable and there are two reasons for our decision. Firstly, the total local expenditures are used as a proxy for the total cost of service provision (Narbón-Perpiñá and De Witte, 2018), and secondly, we were only able to obtain the data for the total local expenditures for local communities in $\mathrm{BiH}$ in the sample for 2017.

Independent variables are gathered at the local level and include a variety of different socio-economic variables together with expenditure assignments of local communities. Again, Narbón-Perpiñá and De Witte (2018) provide an exhaustive list of the independent variables in the works of different authors that used SFA in evaluating inefficiency of local communities. Similar has been summarized for the set of former Yugoslav countries (Table 1). Hence, due to data limitation and some differences in inter-entity methodology of reporting, we have used the following independent variables: population presented as number of resident population, number of pupils in elementary schools, number of doctors (without dentists), number of employed persons and population density (population per $\mathrm{km}^{2}$ ). The independent variables for the case of $\mathrm{BiH}$ were selected based upon their importance in theory and practice in terms of local expenditure assignments in $\mathrm{BiH}$. For control variables, similar to papers by Radulovic and Dragutinovic (2015) for Serbia, the aging index and length of local asphalt roads were used as factors that could explain inefficiency. Independent and control variables are usually summarized as efficiency determinants in groups, as it can be seen in the papers by, for example, 
Nikolov and Hrovatin (2013), Nikolov and Brosio (2015) for the case of North Macedonia or Štastná and Gregor (2015) for the case of the Czech Republic. In these papers and several others (for example Geys 2006, Geys and Moesen 2008 or Kalb, Geys, and Heinemann 2011) additional control variables, particularly political variables, have been used. In the papers by Nikolov and Hrovatin (2013) and Nikolov and Brosio (2015), the third control variable set as a dummy variable is the position of the local communities mayors' political affiliation. MAYCENT control variable with a value of zero (0) states that the political affiliation of the mayor is the same as the entity's central government coalition and a value one suggests otherwise. This has been done for both entity governments (FBiH and RS) for 2016 the year of the latest local elections. Local elections in $\mathrm{BiH}$ are being held every four years. Indicators of independent variables and control variables used in stochastic parametric analysis together with the sources of data for each variable are presented in Table 2.

The list of other possible independent variables for the case of $\mathrm{BiH}$ would have been more exhaustive if the data availability would have been more comprehensive in $\mathrm{BiH}$. Other local communities' expenditure assignments that could potentially be included in the case of $\mathrm{BiH}$ include, inter alia, the number of children in preschool/number of kindergartens or the number of water and sewage service connections.

Expenditure assignments at local level in both entities are very similar with certain inter-entity differences. For example, one difference relates to financing the so-called 'material expenses' of elementary and secondary schools, as well as pupil transport in the RS (Basarić et al. 2018). In the FBiH, local communities in only three cantons are given the function of financing material expenses of elementary schools and pupil transport. These expenditures are usually assigned to cantonal level in most cantons in $\mathrm{FBiH}$. Other differences also exist, for example the unique position of local communities in the Sarajevo Canton in terms of local communal services.

Most selected independent variables in the model are also used in the revenue distribution formulae from higher government tiers towards local communities in both entities. In both entities, shared revenues from indirect taxes (VAT, excise duties, customs, and road fees), which take the highest share of total local revenues, are all allocated depending on, inter alia, the population criteria, the spatial size of the local community and pupils in primary educationiii.

Table 2. Indicators of selected variables for local communities in $\mathrm{BiH}$ and sources of data, 2017

\begin{tabular}{|c|c|c|}
\hline \multicolumn{2}{|c|}{ Variable } & \multirow{2}{*}{$\begin{array}{l}\text { Explanation of variable } \\
\text { Total annual local expenditures (CPI foundation, data for 2017) }\end{array}$} \\
\hline 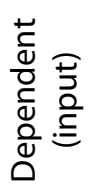 & Total local expenditures & \\
\hline \multirow{5}{*}{ 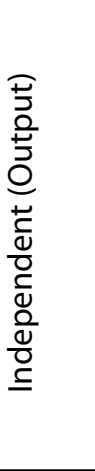 } & Population & $\begin{array}{l}\text { Total resident population in local community (Institute for Statistics of the FBiH } \\
\text { and RS Institute of Statistics, data for 2017) }\end{array}$ \\
\hline & Population density & $\begin{array}{l}\text { Population of a local community per km2 (Institute for Statistics of the FBiH and } \\
\text { RS Institute of Statistics, data for 2017) }\end{array}$ \\
\hline & Education & $\begin{array}{l}\text { Number of pupils in primary schools (Institute for Statistics of the FBiH and RS } \\
\text { Institute of Statistics, data for 2017) }\end{array}$ \\
\hline & Health services & Number of doctors (without dentists, per Census data of 2013) \\
\hline & Employment & $\begin{array}{l}\text { Total number of employed persons in local community (Institute for Statistics of } \\
\text { the FBiH and RS Institute of Statistics, data for 2017) }\end{array}$ \\
\hline \multirow{3}{*}{ 㝑 } & $\begin{array}{l}\text { Structure of public service } \\
\text { provision }\end{array}$ & $\begin{array}{l}\text { Aging index is given as a ratio of the number of residents above } 65 \text { to the number } \\
\text { of residents under } 14 \text { in local community (Institute for Statistics of the FBiH and } \\
\text { RS Institute of Statistics, data for 2017) }\end{array}$ \\
\hline & Road maintenance & $\begin{array}{l}\text { The length of local asphalt roads maintained by local communities (per Census } \\
\text { data of 2013) }\end{array}$ \\
\hline & MAYCENT (dummy) & $\begin{array}{l}\text { Mayor's political affiliation in relation to entity's central government coalition } \\
\text { (zero - the same, one otherwise) (Central Election Commission } \mathrm{BiH} \text {, data for 2017) }\end{array}$ \\
\hline
\end{tabular}

Source: Authors. 
As per available literature related to the SFA method, we assume that a local community is technically inefficient if it uses more inputs than it is necessary to reach the given level of output with the minimum possible cost. To derive the best practice frontier, we need to choose a convenient combination of dependent and independent variables and to decide which approach we will use: parametric or non-parametric. Our goal is to attribute the deviations from the best practice frontier to inefficiency. The literature recognises two types of deviations: deterministic and stochastic. This leads us to four different classes of method: parametric deterministic, non-parametric deterministic, parametric stochastic and non-parametric stochastic methods (Radulovic and Dragutinovic 2015). As previously noted, we implement SFA which is a parametric stochastic method.

SFA was independently proposed by Aigner, Lovell, and Schmidt (1977) and Meeusen and van den Broeck (1977). This approach allows observations to depart from the frontier due to effects of statistical noise and technical inefficiency (Coelli et al. 2005, Deprins and Simar 1983). Based upon the explanation provided by Jondrow et al. (1982, p. 234), SFA is based on the functional form with a given number of parameters and enables one to estimate technical inefficiency as a deficiency of output from its maximal possible value given by the stochastic frontier.

We have stated that we use total local expenditures as a dependent variable which estimates cost inefficiency. Hence, Kumbhaktar, Wang, and Horncastle (2015) state that there are two sources of cost inefficiency which could be reduced to minimize the cost at the same level of dependent variables. These relate to allocative and technical inefficiency. Allocative inefficiency could be improved with the best possible combination of inputs which would mean that there is a different allocation of total expenditures among local communities, in the sense that cost is the smallest. Since we cannot affect the allocative inefficiency, we assume that total local expenditures are efficiently allocated. By reducing technical inefficiency and minimizing total local expenditures, the overall efficiency of $\mathrm{BiH}$ local communities with the same level of outputs is expected to increase. In $\mathrm{BiH}$ analysis, we focus on local communities with the objective to provide a given level of output with a minimum possible cost. We also assume that the local community is technically inefficient - it either provides less than the maximum possible output or uses more input than is necessary to provide the given level of output.

In this paper, we use the method proposed by Battese and Coelli (1995), where the stochastic frontier model, as a linearized version of the logarithm of the Cobb-Douglas functioniv, is specified by

$\ln C_{i}=\beta_{0}+\sum_{r=1}^{k} \beta_{r} \ln X_{i r}+V_{i}+U_{i}$

where $\beta=\left(\beta_{1}, \beta_{2}, \ldots, \beta_{k}\right)$ is a vector of unknown parameters to be estimated, and the error term is made up of two independent parts: $V_{\mathrm{i}}$ is a noise error term, which is normally distributed and represents independent random variables, while $U_{\mathrm{i}}$ is a non-negative inefficiency error term, which captures the effect of the economic inefficiency, often assumed to be halfnormally distributed. Since we focus on examining technical inefficiency, $U_{i}$ is referred to as technical inefficiency.

The technical efficiency for i-th local community is defined in the context of stochastic frontier model (1) as

$$
T E_{i}=\exp \left(-U_{i}\right)
$$

Additional control (explanatory) variables are used to explain the differences in the inefficiency effects $U_{i}$ among the local communities, i.e. the technical inefficiency effects are expressed as a linear function of a vector of local communities' control variables and a random error by

$U_{i}=\delta_{0}+\sum_{t=1}^{s} \delta_{t} z_{t}+W_{i}$

where $\delta=\left(\delta_{0}, \delta_{1}, \ldots, \delta_{s}\right)^{T}$ is a vector of unknown parameters to be estimated, $z=\left(z_{1}, z_{2}, \ldots, z_{\mathrm{s}}\right)$ is a vector of a control variables and $W_{i}$ are random variables.

The applied method was originally developed for the estimation of cost inefficiencies of firms, but it has been extensively applied in the estimation of the cost inefficiencies of local communities. Motives for identifying inefficiency for firms are clear and relate to their main purpose of maximizing shareholders' value, while in the case of public sector, namely local communities, the motives are quite different. Motives should be related to an adequate and efficient use of public funds in the provision of the best quality public goods and services together with solving citizens' problems and satisfying local needs.

Stochastic frontier model, where the inefficiency effects $U_{\mathrm{i}}$ have a systematic component, is expressed as an explicit function of a vector of local communityspecific variables and a random error, which means that the effect of non-discretionary influences on local communities' performance is recognised. 
Table 3. Descriptive statistics of the selected indicators for local communities in $\mathrm{BiH}, 2017$

\begin{tabular}{|c|c|c|c|c|}
\hline Variable & Mean & Std. Dev. & Minimum & Maximum \\
\hline Total local expenditures (in BAM) & $12,030,708$ & $21,116,880$ & 823,618 & $220,832,096$ \\
\hline Population & 25,945 & 27,568 & 354 & 180,053 \\
\hline Population density (population per km2) & 171 & 627 & 2 & 6,529 \\
\hline Pupils in elementary schools & 2,162 & 2,426 & 18 & 15,964 \\
\hline Number of doctors & 46 & 109 & 1 & 850 \\
\hline Employed persons & 5,457 & 8,441 & 100 & 66,304 \\
\hline Aging index & 0.98 & 0.52 & 0.24 & 2.77 \\
\hline Length of local asphalt roads (in $\mathrm{km}$ ) & 96.0 & 79.5 & 7 & 505 \\
\hline
\end{tabular}

Source: own calculation based on data available from BHAS (2016), Institute for Statistics of the FBiH (2018) and RS Institute of Statistics (2018) and CPI (2017).

\section{RESULTS AND DISCUSSION}

In Table 3, we provide a brief analysis of descriptive statistics of the variables of interest for the econometric estimation of the parameters affecting the function of total local expenditures in $\mathrm{BiH}$ in 2017.

From the results presented in Table 3, we can determine variability in the entire dataset which is reflected in the dependent and independent variables. Population living in the local community is one of the most important proxies for the extent of administrative tasks provided by the local community (Kalb, Geys, and Heinemann 2011, Radulovic and Dragutinovic 2015). Also, the theory of fiscal decentralization (see for example Litvack and Oates 1971) suggests that as the population grows at the sub-national level (SNL), SNL's expenditures tend to rise.

In Table 4, we provide summary statistics for the dummy variable related to mayor's political affiliation in relation to entity's central government coalition in both entities. We conclude that two thirds of mayors come from the ruling political coalition in both $\mathrm{BiH}$ entities.

Table 4. Mayor's political affiliation in relation to entity's central government coalition, 2017

\begin{tabular}{|l|c|c|}
\hline Mayor & Frequency & Percent \\
\hline Same party (0) & 86 & 67.19 \\
\hline Not the same party (1) & 42 & 32.81 \\
\hline
\end{tabular}

N.B. Number of observations is 128 due to the fact that in 2016, local elections were not held in the city of Mostar.

Source: authors.

The stochastic frontier cost function determined for the cross-sectional data on $\mathrm{BiH}$ local communities, which is a linearized version of the logarithm of the Cobb-Douglas function, is defined by

$\ln \left(\right.$ Total expenditures $\left._{i}\right)=\beta_{0}+\beta_{1} \ln ($ Population

$+\beta_{2} \ln \left(\right.$ Population density $\left.y_{i}\right)+\beta_{3} \ln \left(\right.$ Pupils $\left._{i}\right)+$

$\beta_{4} \ln \left(\right.$ Employed $\left._{i}\right)+\beta_{5} \ln \left(\right.$ Doctors $\left._{i}\right)+V_{i}+U_{i}$

Table 6 provides the results for two different models of the stochastic parametric estimation of the total local expenditures. The first model, Model 1, includes only the effect of five independent (output) variables (population, population density, pupils in elementary schools, employed persons and doctors), while the second model, Model 2, provides information on model 1 independent (output) variables with three additional control variables (aging index, lengths of asphalt roads and MAYCENT). Three additional control variables are used to explain the differences in the inefficiency effects among the local communities, i.e. the technical inefficiency effects are assumed to be defined by

$U_{i}=\delta_{0}+\delta_{1}$ Aging index

$+\delta_{2}$ Asphalt road $_{i}+\delta_{3}$ MAYCENT $+W_{i}$

where $\delta=\left(\delta_{0}, \delta_{1}, \delta_{2}, \delta_{3}\right)$ is a vector of unknown parameters to be estimated and $W_{i}$ are random variables.

The selected control variables should enable an upgraded measure of local communities' inefficiency, and they are included in the model as a proxy for quality in the provision of public services:

- Length of asphalt roads, as presented in Table 2, refers to the quality of infrastructure (i.e. local community uses public funds efficiently by providing better road maintenance and infrastructure) 
- Aging index, as presented in Table 2, refers to the structure of public service provision, primarily the quality of health care

- MAYCENT refers to a political variable in the decision-making complexity and transparency process. Following the literature, arguments for political variables may be mixed, but it is usually considered that when mayors and the central government come from the same political coalition, they have a stronger incentive to decrease costs and hence increase efficiency (Nikolov and Hrovatin 2013, Nikolov and Brosio 2015). As per available literature, we have also tested Model 2 for the other political variable - the relationship between mayors' and the local assembly's political affiliation, but since majority of mayors and local assemblies come from the same political party, there was not enough variability in the variable to be included in the model.

Before we estimate inefficiency, it is interesting to estimate efficiency levels for each local community, which may be used to identify under-performing local communities and those which are closer to efficiency frontier. For such purposes, we calculated the efficiency index (Figure 1). Calculating the efficiency index of each observation is similar to extracting signal from noise (Kumbhakar, Wang, and Horncastle 2015). We had to find a conditional mean of $U_{i}$ of given composed error term $U_{i}+V_{i}$, i.e. $E\left(U_{i} \mid U_{i}+V_{i}\right)$. Intuitive interpretation of efficiency index for each local community is that higher values of the index indicate a higher level of efficiency of a local community. Our results show that $\mathrm{BiH}$ local communities are relatively inefficient. In fact, the efficiency index is very low in almost all local communities in BiH (Figure 1). However, in the top group of those local communities where efficiency index (Model 2) is greater than 0.9, there are 19 local communities or 14.84 percent of our sample. Table 5 represents summary statistics of efficiency estimates for models 1 and 2 .

Table 5. Summary statistics of the efficiency estimates

\begin{tabular}{|lcc|}
\hline & Model 1 & Model 2 \\
\hline Mean & 0.6740531 & 0.6813051 \\
Minimum & 0.1343294 & 0.1009963 \\
Maximum & 0.9600821 & 0.9667136 \\
Std. Dev. & 0.1807658 & 0.1952432 \\
\hline
\end{tabular}

N.B. Number of observations in Model 1 is 129 and in Model $2-128$.

Source: authors.

From Table 5 we can conclude that the average efficiency index from the parametric models, Model 1 and Model 2, are similar to each other. On average, the minimum cost due to technical inefficiency (Kumbhakar, Wang, and Horncastle 2015) is about 67.4 and 68.1 percent of actual cost for Model 1 and Model 2 respectively. According to Kumbhakar, Wang, and Horncastle (2015), this means that, on average, BiH local communities' total expenditures can be reduced by $48.37 \mathrm{~V}$ percent in Model 1 and by 46.84 percent in

Figure 1. Distribution of technical efficiency index for Model 1 and Model 2

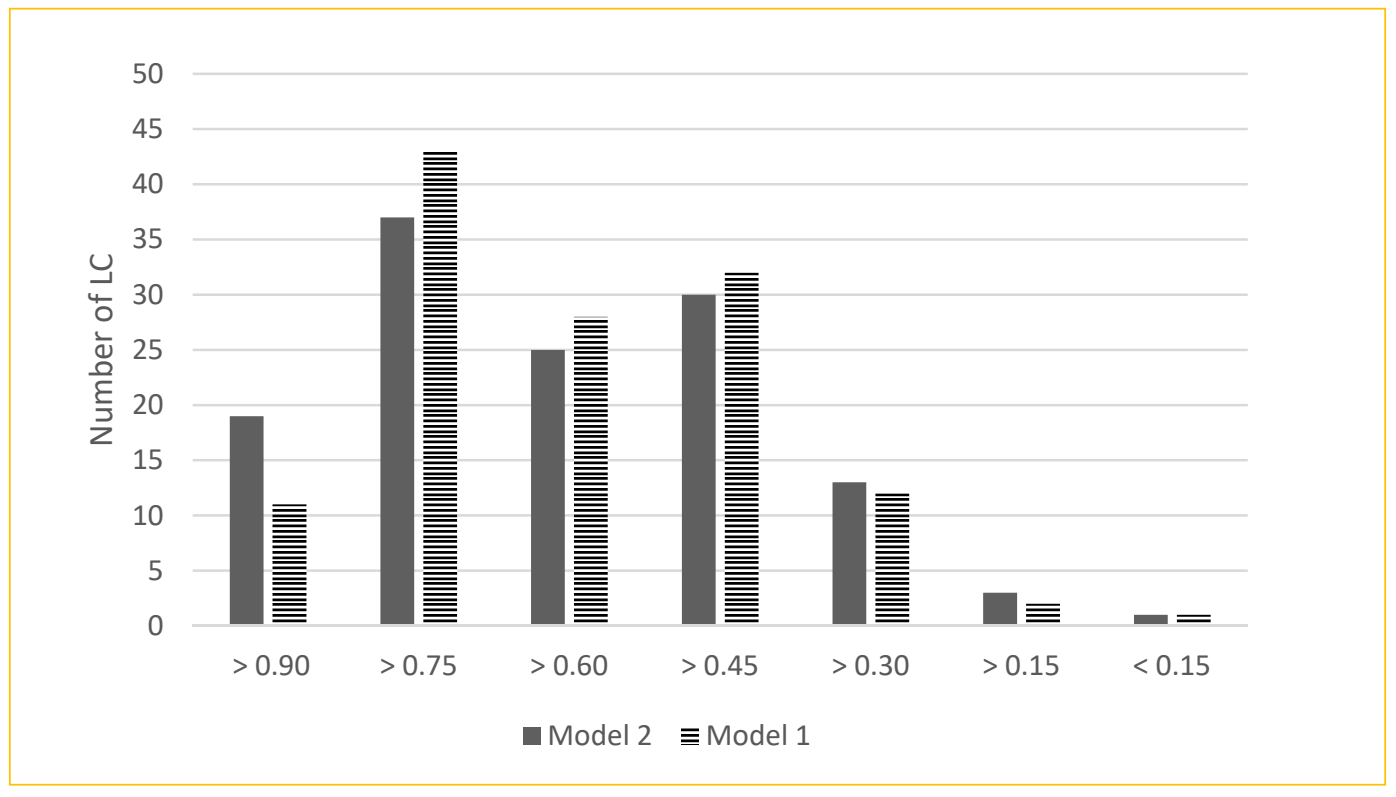

Source: Authors. 
Table 6. Results of Cobb-Douglas type SFA estimation

\begin{tabular}{|c|c|c|}
\hline Variable & Model 1 & Model 2 \\
\hline \multicolumn{3}{|c|}{ Stochastic frontier } \\
\hline Constant $(\beta 0)$ & $9.5172^{* * *}(17.04)$ & $8.8677^{* * *}(16.44)$ \\
\hline In Population & $0.3329^{* * *}(3.95)$ & $0.3959^{* * *}(5.02)$ \\
\hline In Population density & $-0.1149 * * *(-3.35)$ & $-0.0732 * * *(-2.89)$ \\
\hline In Pupils in elementary schools & $-0.1024^{* *}(-2.54)$ & $-0.0728^{* *}(-2.09)$ \\
\hline In Number of doctors & $0.1441^{* * *}(2.62)$ & $0.0820 *(1.68)$ \\
\hline In Employed persons & $0.4317^{* * *}(6.88)$ & $0.4137^{* * *}(8.35)$ \\
\hline \multicolumn{3}{|c|}{ Inefficiency model } \\
\hline Constant $(\delta 0)$ & & $-3.16887^{* * *}(-6.94)$ \\
\hline Aging index & & $1.5229^{* * *}(4.68)$ \\
\hline Length of local asphalt roads & & $0.00407^{* *}(2.50)$ \\
\hline MAYCENT & & $-0.2723(-0.94)$ \\
\hline $\mathrm{N}$ & 129 & 128 \\
\hline$\sigma^{2}$ & 0.0154 & 0.01102 \\
\hline$\gamma$ & 0.9508 & 0.9682 \\
\hline $\mathrm{LL}$ & -42.7449 & -28.8149 \\
\hline LR test of the one sided error & $12.1836^{* * *}$ & $40.0435^{* * *}$ \\
\hline
\end{tabular}

N.B. In Model 2, one observation is missing, due to no elections in the city of Mostar in 2016 which affected the MAYCENT variable.

Note: Significance: ${ }^{* * *} 1 \%,{ }^{* *} 5 \%,{ }^{*} 10 \%$.

Source: Authors.

Model 2 without reducing output levels to achieve the result of the local community on the best practice frontier.

The results of the stochastic parametric estimation of the total expenditures of $\mathrm{BiH}$ local communities are presented in Table 6 . The results are obtained using Stata/SE 12.0 software and commands developed and explained in Kumbhakar, Wang, and Horncastle (2015). Table 6 shows results of the two models. As noted before, Model 1 refers to a baseline Cobb-Douglas model for $\mathrm{BiH}$ local communities without control variables whereas Model 2 investigates the effect that control variables have on the inefficiency. Model 2 also provides an insight into the way the structure of public service provision, road maintenance and political affiliation of the mayor influence the efficiency of BiH local communities.

The estimated coefficients for independent variables on the frontier function of both models are statistically significant. Comparing the coefficients for independent variables of Model 1 and Model 2 we may notice that they are quite similar, showing that our findings are relatively robust to alternative specifications.

Resident population, employed persons and the number of doctors are statistically significant variables with positive coefficients, which indicates their positive relationship to total expenditures. The coefficient related to elasticity of the employed persons is 43 percent, which is the largest of the observed independent variables.

Two variables that are statistically significant and have negative coefficients in both models (Model 1 and Model 2) include population density and pupils in elementary education, which means that the two variables have a negative relationship to total expenditures. Table 6 also gives the results for the control variables. The length of local asphalt roads and aging index are two variables that are statistically significant and have a positive coefficient. The positive coefficient next to the length of asphalt roads variable as a quality of infrastructure indicates that local communities with more responsibility for local infrastructure are more technically inefficient. However, this relationship is very weak because the positive coefficient is very small relative to its standard error. The other positive coefficient next to the aging index variable indicates that local communities with a higher aging index are more technically inefficient. Even though it proved to be a significant variable in other papers (for 
example Kalb, Geys, and Heinemann 2011 or Nikolov and Hrovatin 2013), political variable MAYCENT is not statistically significant in our model. However, the negative coefficient is an expected relationship between the local and central government coalition as shown in the papers by Eeckaut, Tulkens, and Jamar (1993) or Athanassopoulos and Triantis (1998).

In Table 6 we also observed that the null hypothesis of no technical inefficiency for Model 1 is rejected since the likelihood ratio (LR) statistic in this model has a value equal to 12.18 , and the critical value at the 0.001 percent significance level of the test is 3.841 (the critical values of the mixed distribution for hypothesis testing can be found at Kodde and Palm (1986)). Our results show that LR statistic in Model 2 has a value equal to 40.0435 , and the critical value at the 0.001 percent significance level of the test is 17.612. It is evident that the null hypothesis of no technical inefficiency for Model 2 is rejected.

The gamma parameters, first used by Battese and Corra (1977) in formulating the likelihood function, are high for both models $(0.9508$ for Model 1 and 0.9682 for Model 2), which indicates that much of the variation in the composite error term is due to the inefficiency component.

Hence, the results of the implementation of the SFA model in the sample of $\mathrm{BiH}$ local communities for 2017 indicate that very few $\mathrm{BiH}$ local communities are efficient. In fact, our results show that local communities can, on average, improve their efficiency by 31.9 percent. Also, the least efficient local community in $\mathrm{BiH}$ could improve their efficiency by 90 percent, whereas the most efficient local community could also improve efficiency by 3.3 percent. Our results are complementary to those presented in the papers by Soko (2018) and Soko and Zorič (2018), which used a different method - DEA method for classifying $\mathrm{BiH}$ local communities based upon their level of efficiency. Even though there are methodological differences between the two methods, the results of both methods indicate relative inefficiency of local communities in $\mathrm{BiH}$. Soko and Zorič (2018) for 2015 found out that only 16 percent of $\mathrm{BiH}$ local communities are efficient, which means that most local communities in $\mathrm{BiH}$ are relatively inefficient. Our results of the efficiency index indicate that in the top group of local communities where efficiency index is greater than 0.9, there are 19 local communities or 14.84 percent of our sample. By implementing the SFA method, our results bring additional value and insight into the discussion of the decomposition of inefficiency of $\mathrm{BiH}$ local communities. These especially relate to positive relationship between inefficiency and aging index and length of asphalt roads. Hence, $\mathrm{BiH}$ local communities should put more effort into increasing their efficiency, for example by trying to take advantage of economies of scale. This is valid for majority of very small local communities in $\mathrm{BiH}$ which should consider joining their resources and providing local services together. In our future research, we expect to test a greater number of variables related to local activities, for example, the number of registered private companies, local communal infrastructure (water and sewage connections) or education (number of pre-school institutions/children in pre-schooling, etc.) and provide a more exhaustive list of suggestions for local policymakers so that they could improve their efficiency.

\section{CONCLUSION}

The purpose of this paper was to measure the level of technical inefficiency in the sample of local communities in $\mathrm{BiH}$ for the year 2017 by using SFA model. By using total local expenditures as a dependent variable and several independent variables, our results indicate that local communities in $\mathrm{BiH}$ were relatively technically inefficient. In fact, our results show that on average, the minimum cost due to technical inefficiency is about 67.4 and 68.1 percent of the actual cost for Model 1 and Model 2 respectively. Hence, in terms of improving efficiency in $\mathrm{BiH}$, local community's total expenditures can be reduced by 48.37 percent in Model 1 and by 46.84 percent in Model 2 without reducing output levels to achieve the result of the local community on the best practice frontier. We have also calculated the efficiency index for local communities in $\mathrm{BiH}$. In the top group of local communities that have the efficiency index greater than 0.9 , there are only 19 local communities or 14.84 percent of our sample for 2017. Similar results were obtained in the implementation of DEA method for 2015, where 23 local communities or 16 percent in $\mathrm{BiH}$ were considered efficient.

However, this research has a few limitations and possible improvements which are planned in the future work on this topic. Data unavailability has set a few limitations and they include:

- technical inefficiency of local communities was measured in a point of time (only for 2017) for a non-randomised sample of local communities;

- allocative inefficiency was not measured since research should include more variables on the local level.

Our further research may include panel data to estimate efficiency scores on cross-time basis as well as to test other variables that may have impact on the efficiency of BiH local communities. 


\section{Endnotes:}

i Brčko District (BD) will not be analysed due to the scope of this paper.

ii Local communities that were excluded from the analysis are: Vukosavlje, Donji Zabar, Istocni Mostar, Istocni Drvar, Jezero, Kupres (RS), Osmaci, Pelagicevo, Novo Gorazde, Bosansko Grahovo, Ravno and Dobretici.

iii Other criteria also exist such as the number of pupils in secondary education, the level of development of local community, etc. Revenues from direct taxes (corporate and personal income taxes) and certain property taxes are also shared revenues in both entities. Some local communities in $\mathrm{BiH}$ have certain types of property taxes as ownsource revenues.

iv Academic research in the available literature also states the possibility of using a Translog function.

v Calculated as: $\frac{1}{0,674}-1$

\section{REFERENCES}

Aigner, D., Lovell, C. A. K. and Schmidt, P. 1977. Formulation and estimation of stochastic frontier production function models. Journal of econometrics 6, (1): 21-37.

Athanassopoulos, A. D. and Triantis, K. P. 1998. Assessing aggregate cost efficiency and the related policy implications for Greek local municipalities. INFOR: Information Systems and Operational Research 36 (3): 66-83.

Basarić, H., Branković, N. and Lazović-Pita, L. 2018. Bosnia and Herzegovina: Local Government Debt. In Fiscal Decentralisation, Local Government and Policy Reversals in Southeastern Europe, edited by W. Bartlett, S. Kmezic and K. Djulic. Palgrave Macmillan, Cham.

Battese, G. E. and Coelli, J. T. 1995. A model for technical inefficiency effects in a stochastic frontier production function for panel data. Empirical economics 20 (2): 325-332.

Battese, G. E. and Corra, G. S. 1977. Estimation of a production frontier model: with application to the pastoral zone of Eastern Australia. Australian journal of agricultural economics 21 (3): 169-179.

Begić, K. 2000. A constitutional framework for fiscal federalism in Bosnia and Herzegovina. In. The Fiscal Decentralisation Initiative for Central and Eastern Europe: Forum on Fiscal Decentralisation in Bosnia and Herzegovina, edited by Zlatić, M. Conference proceedings. FDI-CEE, Sarajevo - Budapest.

BHAS - BiH Agency of Statistics. 2016. Census of population, households and dwellings in $\mathrm{BiH}, 2013$, final results. Sarajevo: BHAS. [Available at: http://www.popis2013.
ba/popis2013/doc/Popis2013prvolzdanje.pdf, access: December 8 2019].

Boetti, L., Piacenza, M. and Turati, G. 2012. Decentralization and local governments' performance: how does fiscal autonomy affect spending efficiency? FinanzArchiv/ Public Finance Analysis: 269-302.

Central Election Commission BiH. 2017. Statistics and Election results for 2016. [Available at: http://izbori. ba/Default.aspx?CategoryID $=501$ \&Lang $=6$ access: 25/1/2019].

Coelli, T. J., Rao, D. S. P, O'Donnell, C. J. and Battese, G. E. 2005. An introduction to efficiency and productivity analysis. Springer Science \& Business Media.

CPI-Centar za zastupanje građanskih interesa. 2017. Baza javnih finansija (Public finance database). [Available at: www.cpi.ba, access: 15/1/2019].

Deprins, D. and Simar, L. 1983. On Farrell measures of technical efficiency. Recherches Économiques de Louvain/ Louvain Economic Review 49 (2): 123-137.

Eeckaut, P., Tulkens, H. and Jamar, M. A. 1993. Cost efficiency in Belgian municipalities. The Measurement of Productive Efficiency-Techniques and Applications. 300-334.

Fox, W. and Wallich, C. 1999. Fiscal Federalism in BosniaHerzegovina: The Dayton Challenge. The World Bank.

Geys, B. 2006. Looking across borders: A test of spatial policy interdependence using local government efficiency ratings. Journal of urban economics 60 (3): 443-462.

Geys, B. and Moesen, W. 2008. Exploring sources of local government technical inefficiency: evidence from Flemish municipalities. No. SP II 2008-18. WZB Discussion Paper.

Hodžić, S. and Muharemović, A. 2019. Fiscal Decentralization and Efficiency of Regional Government in Croatia: A Data Envelopment Analysis. Lex Localis 17 (3): 453-470.

Institute for Statistics of the FBiH. 2018. Cantons in numbers. [Available at:www.fzs.ba, access: 25/12/2019].

Jondrow, J., Lovell, C. A. K., Materov, I. S. and Schmidt, P. 1982. On the estimation of technical inefficiency in the stochastic frontier production function model. Journal of econometrics 19 (2-3): 233-238.

Kalb, A., Geys, B. and Heinemann, F. 2011. Value for money? German local government efficiency in a comparative perspective. Applied economics 44 (2): 201-218.

Kodde, D. A. and Palm, F. C. 1986. Wald criteria for jointly testing equality and inequality restrictions. Econometrica: journal of the Econometric Society: 1243-1248.

Kreso, S. 2005. Fiscal decentralization in BiH. In: International Symposium: Bosnia and Herzegovina from past to present. Çanakkale: ÇanakkaleOnsekiz Mart University. 241-259.

Kumbhakar, S. C., Wang, H. and Horncastle, A.P. 2015. A practitioner's guide to stochastic frontier analysis using Stata. Cambridge University Press.

Litvack, J. M. and Oates, W. E. 1970. Group size and the output of public goods: Theory and application to 
state-local finance in the United States. Public Finance $=$ Finances publiques 25 (1): 42-62.

Meeusen, W. and van Den Broeck, J. 1977. Efficiency estimation from Cobb-Douglas production functions with composed error. International economic review: 435-444.

Narbón-Perpiñá, I. and De Witte, K. 2018. Local governments' efficiency: a systematic literature review-part I. International Transactions in Operational Research 25 (2): 431-468.

Nikolov, M. and Brosio, G. 2015. Efficient delivery of local public services in ethnically fragmented municipalities. Lex Localis 13 (3): 299.

Nikolov, M. and Hrovatin, N. 2013. Cost efficiency of Macedonian municipalities in service delivery: does ethnic fragmentation matter? Lex localis-Journal of Local Self-Government 11 (3).

Pevcin, P. 2013. Costs and Efficiency of Municipalities in Slovenia. Lex Localis-Journal Of Local Self-Government 11 (3).

Pevcin, P. 2014. Efficiency levels of sub-national governments: a comparison of SFA and DEA estimations. The TQM Journal.

Rabar, D. 2013. Assessment of regional efficiency in Croatia using data envelopment analysis. Croatian operational research review 4 (1): 76-88.

Radulovic, B. and Dragutinovic, S. 2015. Efficiency of local selfgovernments in Serbia: an SFA approach. Industrija 43 (3): 123-142.

RS Institute of Statistics. 2018. Municipalities and cities in Republika Srpska. [Available at:www.rzs.rs.ba, access: 15/11/2019].
Škuflić, L., Rabar, D. and Šokčević, S. 2010. Assessment of the efficiency of Croatian counties using data envelopment analysis. Economic research-Ekonomska istraživanja 23 (2): 88-101.

Soko, A. 2018. (Dis) Advantages af Decentralization Models Driven by Non-Economic Reasons: The Case of Bosnia and Herzegovina. South East European Journal of Economics and Business 13 (1): 81-92.

Soko, A. and Zorič, J. 2018. Municipal efficiency and economies of scale in Bosnia and Herzegovina. Lex Localis 16 (4): 715-734

Štastná, L. and Gregor, M. 2011. Local government efficiency: evidence from the Czech municipalities. No. 14/2011. IES Working paper.

Štastná, L. and Gregor, M. 2015. Public sector efficiency in transition and beyond: evidence from Czech local governments. Applied Economics 47 (7): 680-699.

Tiebout, C. M. 1956. A pure theory of local expenditures. Journal of political economy 64 (5): 416-424.

Web of Science. 2019. Search results from Webofknowledge. [Available at: https://apps.webofknowledge.com/WOS_ GeneralSearch_input.do?product=WOS\&search_mode $=$ GeneralSearch\&SID=E3VjrsmxDJ8KCz981 bu\&preferen cesSaved=, access: 15/1/2019].

Werner, J., Guihéry, L. and Djukic, O. 2006. Fiscal Federalism in Bosnia and Herzegovina. The Journal of Economic Asymmetries 3 (2): 125-148. 